\title{
The Role of the Quality Production Process of the Business Entitles in Volatile Environment
}

\author{
Anvar V. Gumerov ${ }^{1}$, Adeliya V. Pavlova ${ }^{2}$, Guzyal M. Kharisova ${ }^{3}$, Sare N. Abdullina ${ }^{2}$, Elena S. Matveeva ${ }^{3}$, \\ Mikhail G. Vyukov² \& Elmira R. Khairullina ${ }^{4}$ \\ ${ }^{1}$ Kazan National Research Technical University named after A. N. Tupolev, Kazan, Russia \\ ${ }^{2}$ Kazan (Volga region) Federal University, Kazan, Russia \\ ${ }^{3}$ Kazan State University of Architecture and Engineering, Kazan, Russia \\ ${ }^{4}$ Kazan National Research Technological University, Kazan, Russia \\ Correspondence: Anvar V. Gumerov, Kazan National Research Technical University named after A. N. \\ Tupolev, Kazan, Russia. E-mail: frau.levina2010@yandex.ru
}

Received: October 24, 2014 Accepted: December 3, 2014 Online Published: December 18, 2014

doi:10.5539/res.v7n1p200 URL: http://dx.doi.org/10.5539/res.v7n1p200

\begin{abstract}
The purpose of the article is to develop the conditions to improve innovation activity of the business entities and find the source of the macroeconomic dynamics. The presented article determines coordination between the positions of general and strategic management in the field of total quality management of a business entity to achieve continuous improvement in all areas of business. The foundation of the submitted work serves the idea of total quality management spread over the strategic planning inside a business structure in terms of institutional transformation of the national economy. This article describes the effects of the company's financial improvement resulting from implementation of the quality tools into the strategic planning system of the industrial business structures. The article is intended for chief managers, executives, researchers dealing with quality management and strategic planning of the business structures.
\end{abstract}

Keywords: business industrial structure, strategic management, continuous process improvement, total quality management, institutional transformation

\section{Introduction}

The current situation in the industrial sector of the Russian economy is characterized by contradictory tendencies showing some post-crisis stabilization on the one hand, and decline in innovation and investment activity on the other (Tatarkin, 2011; Lavrikova, 2008).

Business structures are independent economic entities the activities of which are subject to business laws and involve constant search for the optimal form of the market conformity at a particular development moment. In terms of institutional deformation and external economic globalization tendencies as well as and companies capitals aggregation, the issues related to improving effectiveness of strategic planning within major industrial clusters, where material and scientific resources concentration is high, become urgent (Webster, 2010; Pauli, 2009; Moiseeva, 2010; Volovikov \& Rebrova, 2010; Druker, 2007).

Despite the fact that the importance of strategic planning for businesses is obvious (Meskon et al., 2004; Vodachek, 1989; Thompson \& Striklend, 2006; Mintzberg, 2002; Hussey, 2004), there are many problems of its adaptation, implementation and tooling in the industrial business entities that require symbiosis of the administrative and market regulation. It seems vital for business structures to organize effective interaction of the subjects, increase financial stability, achieve perspective development goals that will ensure sustainable development of the real sector of the Russian economy.

A paradigm shift from technocratic strategic planning to integrational one defines the preferred growth areas for business structures, which are based on commitment to quality products, meeting customers' requirements and continuous improvement activities caused by market demand and competitive advantage. Thus, strategic planning is closely connected with the company's quality management that is responsible for the quality of processes, products, management, structures interaction. The underdeveloped mechanism of strategic planning, the problems in the theory 
and methodology in current market conditions challenge efficiency, models design, determination of the planning and controlling tools in the industrial corporations activities, which will allow to employ their inherent resource potential, absolute and relative competitive advantages (Kozyrev \& Makarov, 2003; Gavrilova, 2008).

\section{Methodological Framework}

The study is based on the research strategy of poly-paradigmatic approach. Here poly-paradigmatic is regarded as the integrating property of the research methodology aimed at the result. It is based on the idea of multiplicity of entities, conditions, factors and processes associated with the object under study, taking into account compatibility, compensatority, correspondence and balancing of the approaches applied.

The synthesis of the process and project approaches allows to determine the structure of the strategic planning process as a closed cycle of the procedures that require implementation of the project (determination of the innovation development vector; search for true development opportunities to identify the objects of business activity and its planning, organization of synergetic effect resulting from joint production, organizational and management activity of the industrial structures constituents; evaluation of strategic alternatives; monitoring strategic plan implementation alongside continuous interaction with operational planning.

The development of the submitted approach and the specificity of the industrial structure strategic planning such as: the interests of the business agents (Adizes, 2007; Kotler \& Keller, 2012); the real effect of the quality management system and its integration with the strategic planning system; poly-variation of the environment determines some additions and specific principles:

- Systemacity principle, the essence of which lies in the understanding the industrial business structure as a socio-economic system that has integrity, borders, integration of all structures and units, the inertia of activity, reliability, and operations stability.

- The principle of expediency, which determines the purpose from the point of value orientated activities;

- The principle of congruence of the stakeholders' interests which determines the agreed strategic decisions.

- The principle of certainty characterizes the presence of quality characteristics (corporate culture, strategic thinking), mission, motivation, focus on customer values, etc.) And quantitative indicators that determine reaching strategic planning goals.

- The principle of discreteness and continuity meets the requirements of continuous improvement of strategic planning on the one hand, and adaptation to the unsteady economic environment on the other, allowing the industrial structure to be an open system capable of self-organization within the selected market development strategy.

- The principle of necessary and sufficient information that enables to perform a multivariative analysis of internal and external environment for the creation of adequate development prognosis.

- The diagnostic principle that determines the progress of the adopted strategic plan reveals evident and latent problems at all stages, its efficiency and the level of achievement.

- The principle of quality redundancy involving perspective vision of the implemented activities in all aspects of quality (production, management, resources, etc.). The implementation of this principle has a significant impact on the effectiveness of creating significant competitive advantages: competitive interaction (competitors communication, customers, employees, as well as financial and other resources system); prognostic vision (approximation of the system into existing and potential conditions); resource optimization and risk analysis.

Conveying "total quality" concept (TQM) (Deming, 2011; Ishikawa, 1988; Crosby, 2004), we state that the products quality of the industrial structure without doubt is determined by the quality of its design processes, development, manufacture and use, that is by the processes of achieving the goals of the strategic plan.

\section{Results and Discussions}

The selected principles allow us to identify the features of strategic planning in business organizations providing the TQM ideology achievement: the strategic plan should respond to the real possibilities of industrial corporation factored in the resources available (Ansoff, 2009; Porter, 1993); the strategy should be systematically implemented; the strategy should contain the optimum range of interests of the interested groups (stakeholders); the strategy should have competitive perspective intended (Fathutdinov, 2008) for achieving "total quality" processes; the strategy should be proactive, i.e. forestall the environment influence; the strategy should be measurable, that is, have indicators of qualitative and quantitative implementation characteristics. 
The developed concepts permit us to submit organizational and economic mechanism of strategic planning for large businesses (industrial enterprises), where the strategic planning process is presented as a way to implement projects of the production process functioning.

The domestic industry faces vital objectives: to significantly increase competitiveness, to ensure the investment attractiveness growth and transition to innovative development, to achieve high and sustainable economic growth. Even under favorable external conditions the solution of these problems requires transition to a qualitatively new level of management distinct with the strategic nature of the decisions, validity, consistency and action effectiveness. Organizational and economic mechanism of formation and development of strategic planning with a target focus on achieving "total quality" in industrial corporation can be presented with the following diagram (Fig. 1).

The authors submit an algorithm for strategic planning of the industrial enterprise corresponding with the poly-paradigmatic process-project approach that comprises the following steps:

I. Formulation of strategic gaps and problems as the basis for a strategic plan taking into account environmental factors and congruence of stakeholders' interests. Untimely identified strategic gaps and mistakes in the management of business entities may subsequently appear in the form of significant events - a drop in profits or sales, lack of benefits and others. It is important to determine what indicators manifest these possible conditions and introduce systemic changes in the production processes.

II. Formulation of the strategic mission, which the headquarters declare as intention, the company's philosophy, values, fundamental ideology guiding activities in all branches of the organization.

III. Establishment of a strategic vision, as the company's development on the basis of the mission determining the vector of development, the establishment of the strategic objective, involvement opportunities for the strategic goals implementing, ensuring the loyalty of the groups of strategic influence. Strategic intentions that form vision determine the long-term target landmarks, the results of which the company should reach by the deadline.

IV. The formation of the enterprise information security, providing coordination of all information works and providing the user with the information resources of necessary features, dynamic properties and available for frequent use on demand.

V. The formation of a strategic planning balanced scorecard based on integration of the planning and quality management balanced scorecard to ensure transparency of activities in order to implement the established strategy.

VI. The development of a strategic plan of the organization as a gradual achievement of the objectives;

VII. Identifying strategic projects of industrial organization and identification of the implementing processes;

VIII. The development of the ways to implement the strategic projects processes to ensure objectives achievement and implementation of the strategic management. 


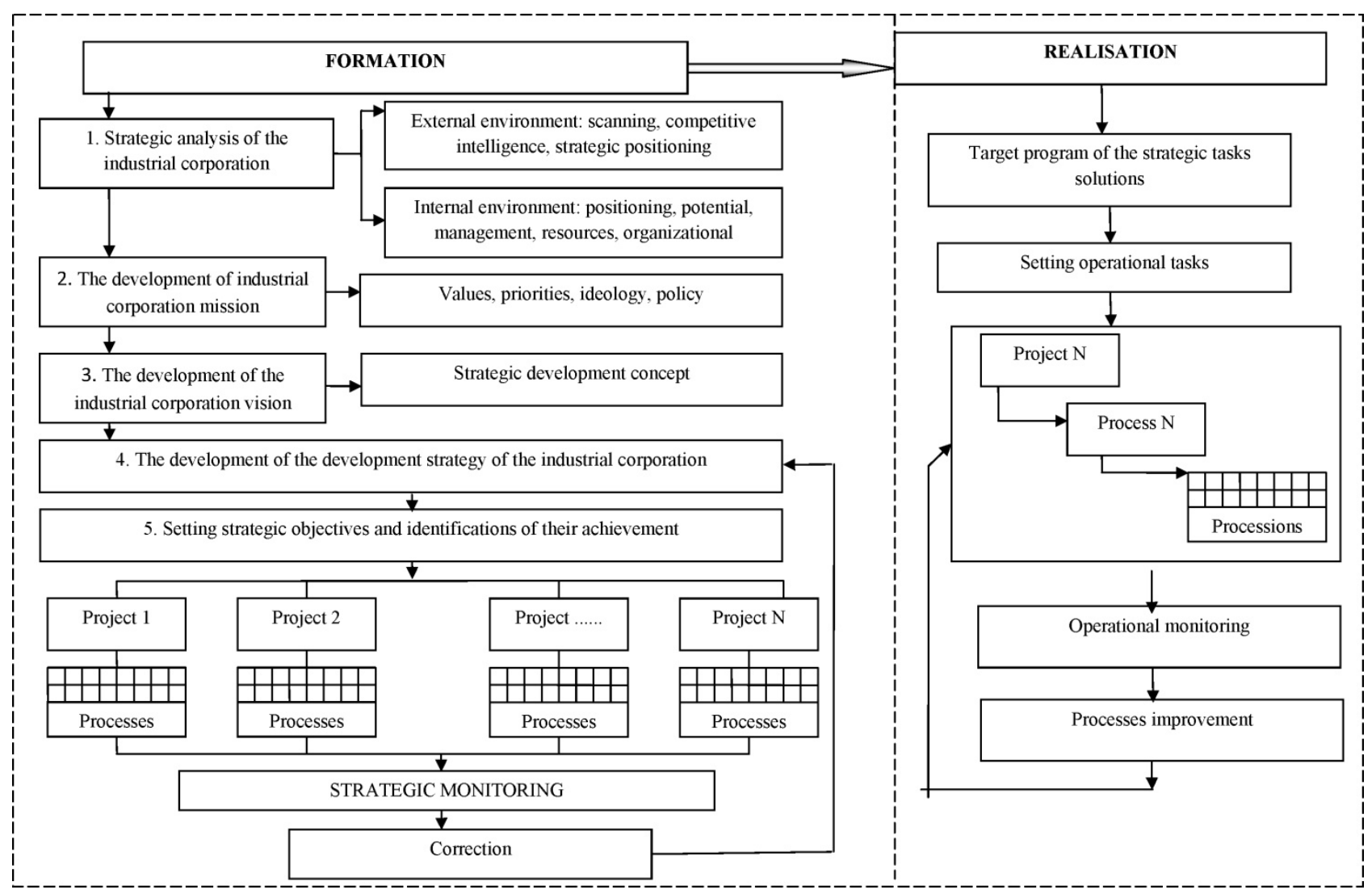

Figure 1. Organizational and economic mechanism of formation and development of strategic planning in the industrial corporation

Every strategic objective is achieved by a specific sequence of actions, processes, projects - by strategic objectives (Figure 2). 


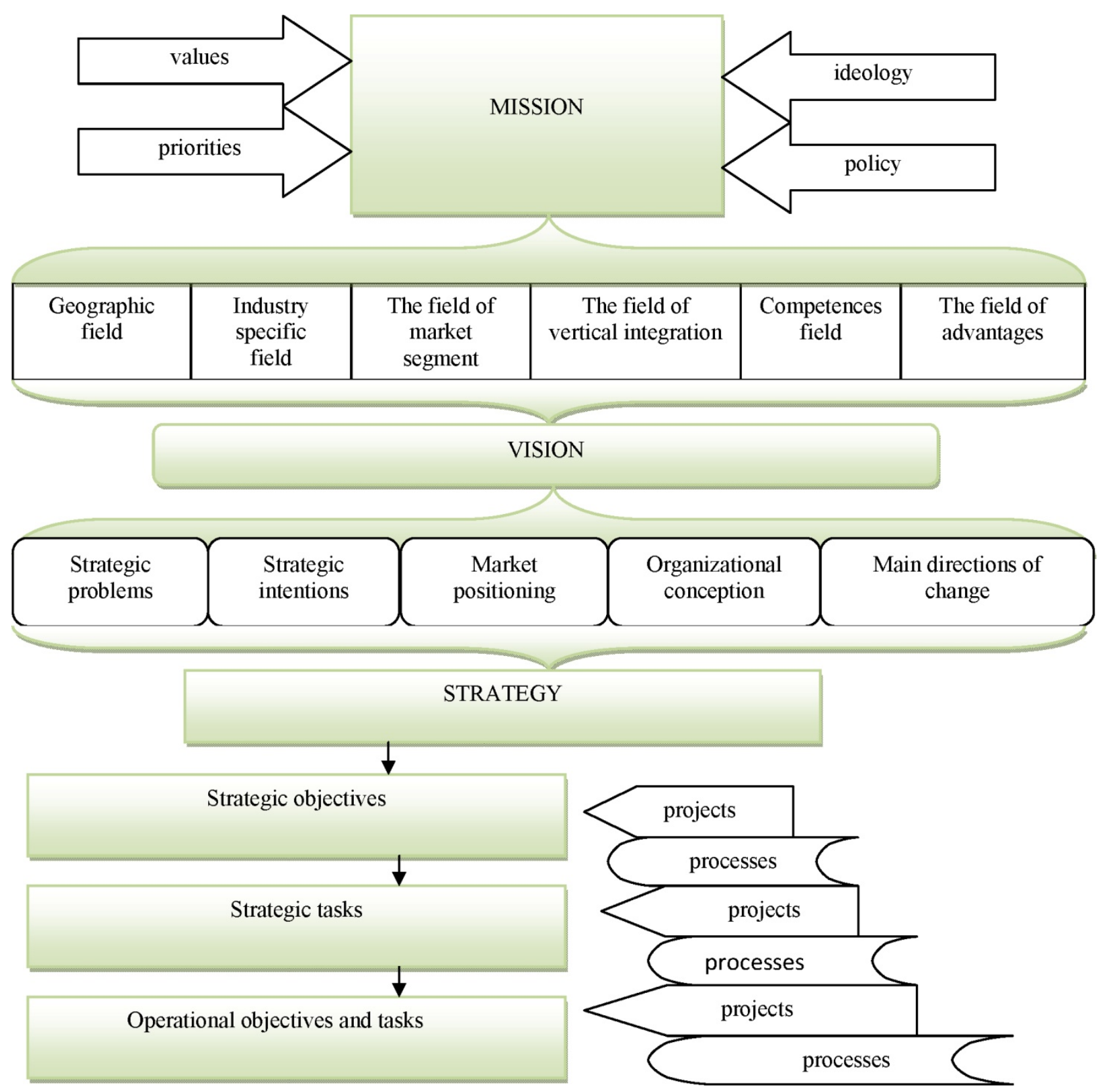

Figure 2. A scheme of the strategy target design for the business structure activity

Every task is connected with one or more objectives and is included into the general strategic plan of the company, aimed at the goals achievement. It is the strategic objectives that bring the strategy into action and ensure its implementation. In the aggregate the strategic objectives form a "portfolio" of the company's strategic projects coordinated between each other and resourced, on the basis of which the operational planning is performed.

Therefore, the well-defined strategic mission with a focus on achieving "total quality" management has the managerial value as it: creates attitudes of senior management towards the long-term plans; triggers the management of all corporation levels to systematically analyze its activities; reduces the risk of short-sighted management; promotes the integration of separate organizational units into the one; develops staff motivation and provides interaction between managers and subordinates at various levels; contributes to the corporate reputation among stakeholders and supports the balance of their interests. 


\section{Conclusions}

Therefore, in the course of the problem investigation, we submitted the project-process approach as the methodology of the strategic planning of the industrial organization as a business structure, proved the strategic planning process as a series of procedures that require project implementation.

The authors have developed the concept of strategic planning of an industrial organization using quality management methods, for which specific principles (systemacity, expediency, congruence of the stakeholders' interests, certainty, discretization and continuity, necessary and sufficient information, diagnosticity, quality redundancy) and the characteristics of the industrial enterprise strategic planning have been identified.

The authors have submitted organizational and economic mechanisms of strategic planning formation and development, where the strategic planning process is presented as a way to implement projects devoted to the production processes functioning in a business structure and an algorithm for strategic planning of the industrial enterprise has been developed.

\section{References}

Adizes, I. (2007). Lifecycle Management Corporation (p. 384). St. Petersburg: Piter Press.

Ansoff, I. (2009). Strategic management (p. 344). St. Petersburg: Piter Press.

Crosby, F. (2004). Quality and Life business in America (p. 264). Moscow: Standards and Quality publishing.

Deming, E. (2011). Out of the crisis: A new paradigm of people management systems and processes (p. 419). Moscow: Alpina Publisher.

Druker, P. (2007). The problems management in the XXI century (p. 127). Moscow: Williams Publisher.

Fathutdinov, R. A. (2008). Strategic Marketing - One of the tooling competitiveness. Journal of Standards and Quality, 3, 60-62.

Gavrilova, M. A. (2008). Competitive potential and its development strategy. Journal of Russian Entrepreneurship, 11, 22-28.

Hussey, D. (2004). Management. Strategy and Planning: A Manager's Guide: E-book. Moscow: Equilibrium Publisher.

Ishikawa, K. (1988). Japanese quality management (p. 214). Moscow: Economics publishing.

Kotler, F., \& Keller, K. L. (2012). Marketing Management (p. 810). Express course. St. Petersburg: Piter Press.

Kozyrev, A. N., \& Makarov, V. L. (2003). Valuation of intangible assets and intellectual property (p. 352). Moscow: World charts Publishing Year.

Lavrikova, Y. G. (2008). The development strategy of socio-oriented industries in the economic space of the largest city (p. 158). Ekaterinburg: Institute of Economics, Ural Branch of Russian Academy of Sciences.

Meskon, M. H., Albert, M., \& Hedouri, F. (2004). Principles of Management (p. 800). Moscow: Science Publisher.

Mintzberg, H., Alstrend, B., \& Lempel, J. (2002). Teaching strategies (p. 336). St. Petersburg, Piter Press.

Moiseeva, N. V. (2010). The strategy of financial recovery. Journal of Financial business, 2, 30-35.

Pauli, N. (2009). Promising strategy. Journal of Management company, 5, 6-9.

Porter, M. (1993). International competition (p. 896). Moscow: International relationship press.

Tatarkin, A. I. (2011). Theory and Methodology of formation of self-evolving socio-economic systems (p. 308). Moscow: CJSC Publishing house" Economy".

Thompson, A. A., \& Striklend, A. (2006). Strategic management: Concepts and situation for analysis (p. 928). Moscow: Williams Publisher.

Vodachek, L. (1989). The strategy of innovation management in the enterprise (p. 167). Moscow: Economics Publisher.

Volovikov, B. P., \& Rebrova, N. P. (2010). Systems approach to the formation of corporate strategies. Journal of Practical Marketing, 9, 32-36.

Webster, F. (2010). Pricing Strategy. Journal of Marketing and market research, 1, 21-37. 


\section{Copyrights}

Copyright for this article is retained by the author(s), with first publication rights granted to the journal.

This is an open-access article distributed under the terms and conditions of the Creative Commons Attribution license (http://creativecommons.org/licenses/by/3.0/). 